\title{
TIONGHOA INDONESIA: DARI DIKOTOMI KE MONO-IDENTITAS?
}

\author{
Ibrahim, S.Fil., M.Si*
}

\begin{abstract}
The most commonly used by various elements in defining Tionghoa identity is by dividing it into main dichotomy, i.e. totok and peranakan. Nevertheless, totok and peranakan definition themselves have limits that keep continuously debated. Totok is generally understood from the side of its birth and Tionghoa Puritanism, while peranakan is comprehended as identity that mixes each other with locality. As the time goes by, totok and peranakan dichotomy are not relevant anymore. Recent politic development has led to Tionghoa identity option measured singly by the level of more liquid flexibility.
\end{abstract}

\section{Key words:}

Tionghoa, Identity, Totok, and Peranaka

\section{PENDAHULUAN}

Pada masa kolonial, identitas etnis Tionghoa ${ }^{1}$ dapat diidentifikasi dalam dua term: totok dan peranakan. Selain riwayat kelahiran, faktor derajat penyesuaian dengan kebudayaan lokal juga menjadi faktor pembeda antara totok dan peranakan. Totok didefinisikan dalam relasinya dengan sejarah kelahiran mereka di negara asal dan tingkat orientasi budaya serta politiknya terhadap negara leluhur mereka, sementara peranakan mengacu pada kelahiran di luar negara China dan derajat penyesuaian diri dengan konteks lokal, misalnya bahasa, agama, nasionalisme, dan sebagainya.

Dikotomi totok dan peranakan pada akhirnya juga cenderung memberikan warna politik yang berbeda. Totok misalnya cenderung mendukung nasionalisme China, sementara peranakan, sekalipun tetap ada

\footnotetext{
* Penulis adalah Dosen Jurusan Sosiologi Fakultas Ilmu Sosial dan Ilmu Politik Universitas Bangka Belitung

1 Istilah 'identitas etnis Tionghoa' yang akan digunakan dalam tulisan ini merujuk pada identitas dalam lingkup yang lebih luas, misalnya identitas agama, budaya, sosial, bahasa, politik, dan sebagainya.
}

yang berorientasi China, pada umumnya mendukung kekawulaan Belanda atau nasionalisme Indonesia. Jika pada masa kolonial orientasi politik etnis ini terbagi dalam tiga corak, maka setelah Indonesia merdeka sikap mereka terpecah dalam beberapa kelompok, yakni integrasionis, asimilasionis, dan cukong. Masing-masing kelompok ini menempuh cara politik yang berbeda-beda dalam mencapai tujuannya. Ketika Indonesia memasuki masa reformasi, corak aktivisme politik menjadi fenomena baru. Dua cara yang dipakai oleh etnis ini adalah gerakan tuntutan untuk mendapatkan hak-hak konstitusional dan keterlibatan dalam berbagai kandidasikandasi Pemilu.

Dalam perkembangan politik mutakhir, definisi identitas etnis Tionghoa yang mengacu pada totok dan peranakan tentu tidak lagi relevan. Pencarian identitas di luar pemilahan tersebut menjadi penting untuk ditelusuri dan menjadi bagian dari gugahan tulisan ini. 


\section{PEMBAHASAN}

Term 'Masalah Tionghoa' yang populer pada masa Orde Baru pada dasarnya memuat substansi dasar mengenai identitas orang-orang Tionghoa yang ada di Indonesia. Perdebatan mengenai bagaimana dan seharusnya seperti apa identitas etnis Tionghoa tersebut ditempatkan oleh penduduk pribumi dan etnis Tionghoa itu sendiri bermuara pada persoalan-persoalan lain di luar sekedar identitas. Itulah sebabnya, Suryadinata (2010:185) mengatakan bahwa persoalan Tionghoa bukan hanya persoalan identitas apa adanya, namun menyangkut ranah yang lebih luas, yaitu politik, ekonomi, dan hubungan internasional. Meski demikian, Suryadinata meyakini bahwa persoalan identitaslah yang kemudian memberi dampak besar bagi perluasan dimensi 'Masalah Tionghoa' dan karenanya persoalan identitas menjadi sangat penting dan pertama-tama harus dijernihkan.

Cara utama yang digunakan oleh Suryadinata (1984:xvii) dalam membahas identitas etnis Tionghoa adalah bagaimana mengidentifikasi etnis Tionghoa dengan memperjelas istilah-istilah utama yang selama ini banyak dipergunakan. Kategorikategori identifikasi etnis Tionghoa yang lazim digunakan seperti ras, bahasa, dan agama dikritik oleh Suryadinata karena menurutnya tidak relevan dengan kenyataan bahwa banyak orang Tionghoa Indonesia yang memiliki latar belakang ras campuran, tidak dapat berbahasa China, dan bukan penganut agama China. Kategori identifikasi diri misalnya dengan cara mengidentifikasi nama keluarga Tionghoa menurut Suryadinata juga tidak relevan karena adanya kebijakan resmi negara untuk mewajibkan orang-orang Tionghoa mengganti nama menjadi khas Indonesia ${ }^{2}$. Istilah yang pertama-tama harus dijernihkan menurut Suryadinata (1984:xviii-xix; $2002: 2 ; 2007: 14 ; 132)$ adalah istilah totok dan peranakan. Istilah-istilah ini membantu untuk mengidentifikasi bagaimana sebetulnya wujud identitas etnis Tionghoa tersebut.

$$
\text { Onghokham }
$$

mendefinisikan totok dan peranakan dari sisi kelahirannya. Menurut Onghokham, istilah peranakan mengacu pada orangorang Tionghoa yang lahir di luar negara China dari seorang totok ${ }^{3}$. Totok adalah pendatang baru dari negara China dan kelahiran Cina. Onghokham menyebut istilah totok dengan istilah singkeh atau singkek $^{4}$ (lihat juga Bertrand, 2004:60; Rahoyo, 2010:63; Tan, 2008:1; Suryadinata, 2007:131; Willmott, 1960:18; Lim \& Mead, 2011:7, Reid, 2009: 289). Keberadaan peranakan menurut Onghokham (2008:169) dipengaruhi oleh fakta sejarah minimnya wanita-wanita Tionghoa yang beremigrasi ke Pulau Jawa sampai pada abad ke-19. Meski demikian, Onghokham meyakini bahwa terdapat pergeseran definisi setelah Indonesia merdeka yang tidak lagi berkutat pada faktor kelahiran dan orientasi budaya.

Sementara itu, totok dan peranakan menurut Suryadinata (1984:xviii-xix)

\footnotetext{
2 Kebijakan pemerintah terhadap etnis Tionghoa diaspora menurut Suryadinata (2002:10-11) dipengaruhi oleh konsep bangsa dimana mereka berada. Jumlah etnis Tionghoa yang ada di suatu negara juga relatif berpengaruh terhadap kebijakan yang diambil oleh pemerintah. Faktor lain adalah sistem politik suatu negara, apakah demokratis atau otoriter.

3 Tionghoa totok menurut Lim \& Mead (2011:10) secara umum adalah orang-orang Hokkien, Cantonese, Hakka, Teochew, dan Hainan.

4 Menurut Williams (1960:10), istilah Singkeh diturunkan dari kata $h$ sin-k'o yang berarti tamu baru.
} 
tidaklah merujuk pada asal-usul kelahiran, melainkan merujuk pada tingkat penetrasinya terhadap kebudayaan lokal. Totok tidaklah didefinisikan sebagai orangorang yang lahir di China dan kemudian tinggal di perantauan (overseas China), namun dilihat dari sejauhmana ia masih berbahasa China dan berorientasi ke negara China. Sementara peranakan mengacu pada etnis Tionghoa yang menggunakan bahasa Indonesia sebagai bahasa sehari-hari di rumah (lihat juga Suryadinata, 2010:183; 2002:17; 1978: 1). Indikator bahasa ini menurut Tan (2008:166-169) menjadi faktor pembeda yang penting untuk mengidentifikasi identitas etnis Tionghoa karena bahasa menyangkut perbedaan pengalaman, sejarah, atau pendidikan.

Dikotomi ini oleh Dawis (2010:54; lihat juga 2010:25; Yamamoto, 2011:109; Lim \& Mead, 2011:7; Freedman, 2000:26) tidak hanya dipandang sebagai dua istilah, namun juga sebagai dua kelompok yang saling berbeda dan pada akhirnya memiliki orientasi yang relatif berbeda. Selain soal orientasi pada negara China, pemilihan istilah totok dan peranakan pada masa kolonial juga terjadi dalam dunia ekonomi, misalnya Tionghoa totok yang lebih memilih menjadi pedagang. Bahkan menurut Tong (2010:112) ada kecenderungan bahwa hubungan antara totok dan perananan memuncak menjadi hubungan yang disharmonis. Hal ini dipicu oleh kalangan totok yang merasa superior dan lebih Tionghoa, sementara peranakan justru cenderung masuk golongan ekonomi tinggi dan menganggap totok sebagai pendatang.

Vasanty

(1999:354)

mengkombinasikan definisi totok dan peranakan antara kelahiran dan derajat penyesuaian. Totok bukan saja orang yang lahir di negara China, namun juga masih memiliki dan mempraktikkan budaya Tionghoa dalam kehidupan sehari-hari. Sementara peranakan, selain lahir di Indonesia, juga sudah beradaptasi secara jauh dalam kehidupan masyarakat pribumi. Analisis yang selama ini dianggap paling memadai mengenai identitas etnis Tionghoa adalah analisis Gungwu (lihat Tan, 1997:39). Gungwu (1988:1-16) mengatakan bahwa identitas Tionghoa saling tumpang tindih, berubah dari waktu ke waktu, saling menyilang, dan selalu tidak bisa dilepaskan dari pencampuran identitas 5 .

Menurut Gungwu (1988:9), ada tujuh identitas etnis Tionghoa yang dapat diidentifikasi, yaitu identitas sejarah (berkaitan dengan sejarah masa lalu orangorang Tionghoa dan terbentuk umumnya sebelum perang dunia kedua. Identitas ini membungkus konsep dengan identitas budaya), identitas nasionalis China (berkaitan dengan orientasi sebagian kelompok terhadap nasionalisme di China yang bangkit pada awal tahun 1900-an. Identitas ini menurut Gungwu sudah sangat tipis untuk tidak mengatakannya sudah tidak ada), identitas komunal (identitas ini bersifat jejaring kuat dan menurut Gungwu dapat dijumpai di Malaysia. Identitas ini dapat berubah menjadi identitas etnis), identitas nasional-lokal (identitas ini berkaitan dengan identitas diri sebagai warganegara dimana mereka berada. Identitas ini umumnya dipegang oleh orang-orang yang berada di wilaya Asia Tenggara), identitas budaya (identitas ini diserap dari tradisi identitas sejarah dan merupakan identitas yang paling lentur), identitas etnis (identitas etnis pada dasarnya

\footnotetext{
5 Chee-Kiong \& Kwok-bun (2001:363) menyebutnya dengan istilah labelitas yang saling bertabrakan, bercampur, dan melebur.
} 
mengoreksi identitas budaya dalam hal orisinalitas ras dan lebih spesifik menyangkut gagasan dari tujuan politik dalam rangka mencapai legitimasi hak-hak minoritas. Konsep ini bertujuan untuk memperoleh simpati dari dunia luar), dan identitas kelas (identitas ini sangat tergantung pada persilangan batas-batas etnis yang tumbuh sebagai sesuatu yang tidak terhindarkan dalam waktu yang lama. Pada titik ini, menurut Gungwu, identitas menjadi sangat tergantung dengan keadaan, termasuk elemen di luar Tionghoa itu sendiri).

Suryadinata \& Peacock sebagaimana dicatat oleh Dawis (2010:83-84) mengemukakan bahwa perkembangan mutakhir etnis Tionghoa menunjukkan ada perbedaan dasar sosial dan budaya yang terbentuk oleh fakta sejarah pemisahan totok dan peranakan pada masa kolonial dan awal kemerdekaan. Orang-orang Tionghoa peranakan menentukan jati dirinya berdasarkan tempat kelahiran mereka di Indonesia dan berorientasi pada Indonesia. Sebaliknya, orang-orang Tionghoa totok lebih sering beriorientasi China atau yang lebih sering lagi adalah orientasi pada tanah tempat kelahiran orangtua atau nenek moyang mereka.

Dengan demikian, mengidentifikasi identitas etnis Tionghoa sesungguhnya tidak dapat dilakukan dengan mudah karena terjadinya heterogenitas identitas dalam tubuh etnis Tionghoa itu sendiri (lihat juga Tan, 1991:119) ${ }^{6}$. Heterogenitas tersebut misalnya menurut Dawis (2010:103) meliputi asal-usul daerah, afiliasi agama, pengaruh keluarga, kelas, patriarki, dan

\footnotetext{
${ }^{6}$ Stavenhagen sebagaimana dicatat oleh Fisher, dkk (2000:46-47) menggunakan kriteria bahasa,agama, wilayah, organisasi sosial, budaya, dan ras untuk menentukan kelompok-kelompok etnis.
}

pencarian jodoh yang mendasari pola interaksi dan identifikasi etnis Tionghoa Indonesia.

Dalam konteks perkembangan politik dan pemerintahan mutakhir yang kemudian berimplikasi pada ruang-ruang sosial dan budaya, dikotomi totok dan peranakan tidak lagi relevan dalam merumuskan identitas etnis Tionghoa. Terutama yang harus dipertanyakan menurut Tan (2008:166) adalah eksistensi Tionghoa totok. Dikotomi identitas tersebut dibentuk oleh fakta sejarah emigrasi orang-orang Tionghoa yang terpaksa bercampur dengan penduduk lokal karena minimnya wanita-wanita dari Cina yang beremigrasi ke Indonesia. Gelombang demi gelombang emigrasi yang kemudian masuk, serta perkembangan politik Indonesia pra kemerdekaan membentuk identitas Tionghoa dalam dua identitas yang saling berseberangan. Situasi ini semakin memudar seiring dengan berkembangnya beberapa hal.

Pertama, Orde Baru telah melakukan proyek asimilasi total yang memaksa orangorang Tionghoa untuk melebur secara penuh dengan menghilangkan identitasidentitas mereka. Di tengah cercaan banyak ilmuwan tentang kegagalan dan dampak buruk dari asimiliasi Orde Baru tersebut, tidak bisa dipungkiri bahwa proyek ini memberikan efek positif bagi bangunan nasionalisme Indonesia orang-orang Tionghoa. Sekalipun Orde Reformasi telah membawa perubahan mendasar pada cara pandang dan perlakuan terhadap orangorang Tionghoa, namun tetap tidak mudah untuk menghapus pengaruh asimilasi tersebut. Artinya, terlanjur banyak orangorang Tionghoa yang sudah menghilangkan identitas ketionghoaan mereka.

Kedua, dikotomi totok dan peranakan mengandaikan masih adanya pengalaman 
dan tuturan langsung orang-orang dari negara China. Hal ini misalnya berlangsung dalam gelombang-gelombang emigrasi orang-orang Tionghoa kelahiran China ke Indonesia pada masa pra kemerdeakaan. Selain sekarang sudah sukar mencari orangorang kelahiran China yang berkwarganegaraan Indonesia, sistem perpindahan kewarganegaraan saat ini juga tidak semudah pada abad-abad sebelumnya. Mobilisasi kwarganegaraan dalam beberapa dasawarsa terakhir ini terikat ketat oleh sistem kwarganegaraan yang berlaku secara internasional. Dengan demikian, orangorang Tionghoa yang ada di Indonesia saat ini diperkirakan merupakan orang-orang yang sudah berstatus peranakan dalam arti kelahiran. Suryadinata (2010:183) mengatakan bahwa berhentinya arus imigrasi Tionghoa ke Indonesia secara otomatis menurunkan jumlah Tionghoa totok di Indonesia, bahkan generasigenerasi totok telah mengalami peranakanisasi.

Ketiga, iklim politik di Indonesia saat ini sedang menuju pada proses demokratisasi dengan elemen-elemen partisipasi, kontestasi, dan ekualitas sebagai ciri dasarnya. Orientasi totok yang pada masa kolonial mengarah pada nasionalisme China kiranya tidak relevan mengingat saluran-saluran politik etnis Tionghoa dapat diakomodir dalam sistem perpolitikan di Indonesia saat ini. Setidaknya hal ini dibuktikan dengan berdirinya berbagai organisasi partai politik berorientasi etnisitas ke-tionghoa-an pada awal reformasi.

Oleh karena itu, identitas etnis Tionghoa perlu didefinisikan di luar dikotomi totok dan peranakan. Pertanyaannya: apakah mungkin memunculkan satu identitas Tionghoa yang sama sekali lepas dari dua istilah dasar tersebut?

$\begin{array}{ccr}\text { Secara } & \text { fisik, } & \text { memang } \\ \text { mengidentifikasi } & \text { orang-orang } & \text { Tionghoa } \\ \text { tidaklah terlampau rumit. } & \text { Rahoyo }\end{array}$
(2010:139) misalnya mengidentifikasi etnis Tionghoa dari mata dan kulit, bahasa yang digunakan, dan nama asli yang dimiliki. Namun Rahoyo, berdasarkan temuan penelitiannya mengemukakan salah satu cara baru untuk mengidentifikasi mereka adalah dengan klaim ideal type yang seharusnya melekat dalam diri orang Tionghoa, yaitu seharusnya kaya. Jika tidak kaya, maka orang-orang Tionghoa itu sendiri akan menanggalkan identitas ketionghoa-annya dan akan lebih memilih membangun hubungan dengan penduduk pribumi. Sementara Usman (2010:330-338) menambahkan aspek lain, yaitu silsilah keturunan darah dan cara mereka mempraktikkan budaya leluhur. Namun ini lagi-lagi masih kontroversial.

Studi Usman (2009) mengenai etnis Tionghoa di Aceh menunjukkan bahwa sekalipun etnis Tionghoa berusaha untuk beradaptasi dengan masyarakat lokal melalui berbagai manipulasi identitas, namun pada batas-batas tertentu mereka tetap memiliki dan memelihara identitas yang menjadi pembeda mereka dengan orang-orang lain. Identitas etnis Tionghoa di Aceh yang menonjol yang diidentifikasi oleh Usman (2009:330) adalah identitas nasional dan lokal, identitas historis dan budaya, serta identitas etnis.

Cara etnis Tionghoa di Aceh mengidentifikasi identitas nasional dan lokalnya adalah dengan melalui bahasa Indonesia dan serapan dari bahasa Aceh. Cara lain adalah dengan penggunaan kartu tanda penduduk. Berkaitan dengan identitas historis dan budaya, etnis Tionghoa di Aceh 
menggunakan identitas ganda. Selain penyesuaian dengan identitas Aceh, etnis Tionghoa di daerah ini pada dasarnya tetap mempertahankan identitas historis dan budaya leluhur mereka, misalnya penggunaan bahasa Khek sebagai bahasa suku, tulisan Mandarin di rumah-rumah, ritual keagamaan, pengunaan nama nasional dan nama keluarga sekaligus, serta penguatan jejaring etnis dalam bisnis. Adapun identitas etnis adalah identitas yang tidak dapat berubah secara alami dan bersifat biologis. Etnis Tionghoa ditandai dengan ciri fisik yang sangat mudah diidentifikasi, misalnya melalui wajah, mata, dan warna kulit ${ }^{7}$. Masyarakat Aceh sendiri memahami etnis Tionghoa dari aspek turunan darah Tionghoa dan praktik budaya Tionghoanya sekaligus (Usman, 2009:330-338).

Studi Usman ini setidaknya mengemukakan informasi penting berkaitan dengan bagaimana etnis Tionghoa memperlakukan identitas-identitas yang mereka miliki. Etnis Tionghoa Aceh menurut Usman (2009:354) tetap berusaha menjaga identitas historis dan budaya Tiongkok sehingga kesan eksklusivitas menjadi tidak terhindarkan. Etnis Tionghoa juga secara politik menurut Usman cenderung terikat oleh doktrin leluhur, yakni secara moral berkewajiban untuk membangun negara leluhurnya. Mereka cenderung membentuk jaringan dengan sesama etnisnya. Manipulasi-manipulasi identitas etnis Tionghoa menurut Usman dilakukan unutuk menyesuaikan diri dengan lingkungan masyarakat setempat seraya

\footnotetext{
7 Menurut Rahoyo (2010:138), dari ciri fisik sebenarnya cukup mudah untuk mengidentifikasi seseorang apakah Tionghoa atau bukan.
}

tetap mempertahankan identitas Tionghoa mereka ${ }^{8}$.

$$
\text { Studi Dawis (2010) juga }
$$

menunjukkan adanya kerinduan orangorang Tionghoa Indonesia terhadap leluhur mereka. Tekanan demi tekanan yang dialami oleh orang-orang Tionghoa di Indonesia membuat mereka berusaha untuk mencari ruang-ruang bagi rekonstruksi jati diri. Media film ber-setting negara Cina adalah salah satu sarana yang menurut Dawis (2010:186-189) membantu etnis ini untuk membentuk rasa solidaritas dan kebersamaan di antara keluarga, tetangga, dan anggota masyarakat lainnya melalui imajinasi-imajinasi tentang Hongkong atau Taiwan.

Upaya penguatan identitas etnis Tionghoa juga pernah distudi oleh Lasiyo (1992). Menurut Lasiyo, etnis Tionghoa tidak dapat melepaskan diri dari warisan leluhur mereka, terutama dalam hal orientasi agama. Meski menganut agama baru, namun etnis Tionghoa masih mempraktikkan agama asli mereka.

8 Manipulasi identitas ke-Tionghoa-an juga dilakukan oleh Rahoyo (2010). Menurut Rahoyo (2010:174-175), etnis Tionghoa sendiri mendefinisikan identitas etnis mereka dengan stereotip kaya secara materi. Ketika Tionghoa tidak dapat keluar dari belitan kemiskinan, maka mereka akan menghilangkan identitas etnis mereka sebagai orang Tionghoa dan lebih memilih mengidentifikasi diri sebagai orang miskin. Ajaran materialisme yang menjadi pandangan hidup membentuk konstruksi berpikir orang Tionghoa bahwa mereka pada dasarnya harus menjadi orang kaya (ideal type), bukan seperti yang terjadi dalam diri Tionghoa miskin (real type). Dalam kasus demikian, orangorang Tionghoa miskin menurut Rahoyo tidak dapat memanfaatkan rasa inferior mereka dan lebih bersifat inferior. Ketika orang-orang Tionghoa miskin memilih jalur identitas kelas sebagai dasar pembentukan jati diri mereka, maka sesungguhnya menurut Rahoyo, mereka telah kehilangan kesempatan untuk mendapatkan manfaat dari identitas etnis, misalnya solidaritas etnis atau yang disebut dengan relasi guanxi. 
Penerimaan agama baru bagi mereka hanyalah bentuk adaptasi dengan lingkungan sekitar ${ }^{9}$. Senada dengan temuan tersebut, Tjhin (2007:335) mengatakan bahwa kesuksesan orang-orang Tionghoa memang sangat dipengaruhi oleh latar belakang sejarah mereka, terutama nilainilai sosial kultural yang berakar pada konfusianisme, tanggung jawab terhadap keluarga, dan pemanfaatan sumber daya dan akumulasi modal. Situasi ini menurut Thjin menjadi faktor penting yang mempengaruhi bisnis etnis Tionghoa. Orientasi kekerabatan etnis Tionghoa sebagai simbol familisme dijaga dengan kuat sehingga tidak mengherankan jika mereka loyal terhadap negeri leluhur mereka.

Huntington

(2000:219;307) mengatakan bahwa ada kecenderungan orang-orang Tionghoa yang menyebar ke berbagai negara tetap terorientasi pada 'tanah air nenek moyang', terutama negaranegara yang didominasi etnis Tionghoa seperti Taiwan dan Singapura yang oleh Huntington disebut sebagai 'Negara Peranakan Cina' dan bergerak berproses menuju unifikasi, yaitu 'Cina Raya'. Studi Erman (2010:13-17) mengenai corak politik etnis Tionghoa di Pulau Bangka pada masa pra kemerdekaan juga menampakkan bahwa komunitas Tionghoa di Bangka memiliki orientasi politik yang erat dengan perkembangan politik komunitasnya di luar daerah dan berorientasi pada pergerakan politik leluhur. Para buruh-buruh tambang

$9 \quad$ Situasi ini menurut Tan (1991:123) dipertegas oleh sebuah riset di Solo yang menunjukkan bahwa totok lebih banyak menjadi muslim ketimbang orang-orang peranakan. Ketika orang-orang peranakan ditanya mengenai fenomena ini, umumnya mereka mengatakan bahwa konversi agama orang-orang totok ke Islam hanya untuk mempermudah urusan bisnis mereka. mengorganisir diri dengan jaringan-jaringan di luar Pulau Bangka dan mengabaikan persoalan lokalitas. Erman menduga bahwa peran intelektual Tionghoa yang masuk melalui sekolah-sekolah Tionghoa menjadi sebab maraknya aksi-aksi pergerakan buruh tambang pada masa kolonial.

$\begin{array}{crr}\text { Jika } & \text { Suryadinata } & (2010: 218-237 \\ \text { menyatakan } & \text { bahwa } & \text { kebangkitan }\end{array}$
kebudayaan etnis Tionghoa sedang terjadi di Indonesia saat ini yang diawali dengan reposisi tiga pilar budaya Tionghoa (pers Tionghoa, sekolah Tionghoa, dan organisasi Tionghoa), tidakkah kemudian ini menandakan bahwa sedang terjadi pergeseran menuju identitas tunggal? Artinya bahwa dikotomi totok dan peranakan memang menjadi tidak urgen, apakah ini berarti ada sebuah identitas baru Tionghoa yang sedang dibangun oleh etnis ini melalui saluran-saluran formal yang tersedia?

Kenyataan menunjukkan bahwa batas-batas identitas menjadi sesuatu yang tidak perlu diperdebatkan. Dalam kasus partisipasi politik elektoral di Kepulauan Bangka Belitung yang mengalami peningkatan dalam satu dasawarsa terakhir ini, kecenderungan menunjukkan bahwa debat-debat mengenai budaya asal, daerah kelahiran, bahasa yang digunakan, agama, sampai pada kepercayaan mereka tidak terlampau berpengaruh. Fokus identitas adalah fokus ketionghoaan yang menyertakan terlesapnya batas-batas heterogenitas. Yang penting kemudian adalah apakah Tionghoa atau bukan? Tionghoa tidak lagi lengkap dengan atribut heterogentitasnya karena adanya nuansa tunggal identitas yang lebih merujuk pada etnis ini atau bukan.

Nyaris menangnya Ahok di Pemilihan Gubernur Kepulauan Bangka Belitung pada 
Pilkada 2007 dan terpilihnya Ahok sebagai Wakil Gubernur DKI Jakarta 2012 lalu menyertakan informasi penting bahwa identitas yang memiliki batas-batas varian tenggelam dalam sebuah kata utama: Tionghoa. Sub-sub identitas pada akhirnya menjadi tidak sepenting pada identifikasi etnisitas secara umum.

Meski masih perlu perdebatan panjang, transisi dari dikotomi kek monoidentitas saya kira patut dipertimbangkan sebagai sebuah cara baru untuk melihat identitas ketionghoaan. Hal ini terutama terlihat dari penetrasi Tionghoa dalam dunia politik yang cenderung meminggirkan basis-basis perdebatan subidentitas. Bagaimana bentuknya, pada batas yang bagaimana, dan daya lesapnya adalah poin pokok yang menarik untuk terus diperbincangkan.

\section{PENUTUP}

Tionghoa Indonesia selalu bergumul dengan debat-debat identitas. Identitas menjadi penting karena pada akhirnya akan bermuara pada bagaimana etnis ini menempatkan identitasnya dalam konteks lingkungan ekonomi dan politik. Cara yang paling umum digunakan untuk mengidentifikasi ketionghoaan adalah dengan cara dikotomi, yakni apakah mereka totok atau peranakan.

Totok dikaitkan dengan kelahiran asli dan daya orisinalitas ketionghoaan, sementara peranakan lebih dikaitkan dengan percampuran atas identitas lokal dimana Tionghoa berada. Seiring dengan perkembangan waktu, memahami etnis Tionghoa dalam dua definisi tersebut kiranya tidak lagi relevan. Pertama, rezim Orde Baru telah memaksakan proyek asimiliasi total terhadap orang-orang Tionghoa dan dengan sendirinya memaksa
Tionghoa totok semakin habis dan tergerus. Kedua, mengandaikan masih adanya Tionghoa totok berarti masih mengandaikan adanya generasi-generasi kelahiran Tiongkok. Padahal waktu yang teramat lama sudah menghilangkan kemungkinan masih banyaknya Tionghoa yang secara langsung lahir di daerah asalnya. Ketiga, iklim demokrasi yang sedang berkembang saat ini memungkinkan Tionghoa tidak lagi memikirkan nasionalisme asal daerah.

Dengan memperhatikan diskursus teoritis dan perkembangan politik yang terjadi, ada kecenderungan bahwa Tionghoa tidak lagi terbelah dalam dikotomi identitas, melainkan lebur dalam sebuah identitas tunggal. Pengalaman politik terbaru menunjukkan bahwa sub-sub identitas menjadi tidak penting, sementara identitas etnisitas lebih dominan. Penelusuran lebih lanjut mengenai bagaimana identitas tunggal tersebut dipahami menjadi debat baru yang menarik.

\section{DAFTAR PUSTAKA}

Bertrand, Jacques, 2004. Nationalism and Ethnic Conflict in Indonesia, Cambridge University Press, Cambridge.

Chee-kiong, Tong dan Chan Kwok-bun, 2001. One Face, Many Masks: The Singularity and Plurality of Chinese Identity dalam Diaspora, 10:3 2001, pp. 361-389.

Dawis, Aimee, 2010. Orang Tionghoa Indonesia Mencari Identitas, PT. Gramedia Pustaka Utama, Jakarta. 
2010. Orang Tionghoa

Berorganisasi, Yang Kini Lanjutan dari Masa Lalu? dalam Setelah Air Mata Kering, Masyarakat Tionghoa Pasca-Peristiwa Mei 1998, Editor I Wibowo dan Thung Ju Lan, Kompas, Jakarta.

Erman, Erwiza, 2007. Deregulasi Tata Niaga Timah dan Pembuatan Negara Bayangan Lokal: Studi Kasus Bangka dalam Politik Lokal di Indonesia, Editor Henk Schulte Nordholt dan Gerry van Klinken dibantu oleh Ireen Karang-Hoogenboom, Yayasan Obor Indonesia-KITLV, Jakarta.

Fisher, dkk., 2000. Mengelola Konflik, Keterampilan dan Strategi untuk Bertindak, diterjemahkan oleh Karikasari, dkk, The British CouncilIndonesia, Jakarta.

Freedman, Amy L., 2000. Political Participation and Ethnic Minorities, Chinese Overseas in Malaysia, Indonesia, and The United States, Routledge, New York dan London.

Gungwu, Wang, 1988. The Study of Chinese Identities in Southeast Asia dalam Changing Identities of The Southeast Asian Chinese since World War II, Editor Jennifer Cushman dan Wang Gungwu, Hong Kong University Press, Hong Kong.

Huntington, Samuel P., 2000. Benturan Antar Peradaban dan Masa Depan Politik Dunia, Diterjemahkan oleh M. Sadat Ismail, Qalam, Yogyakarta.
Lasiyo, 1992. Agama Konghucu, An Emerging Form of Religious Life Among The Indonesian Chinese, Disertasi Doktor, University of London School of Oriental and African Studies, Center of Religion and Philospohy.

Lim, Hermanto dan David Mead, 2011. Chinese in Indonesia: A Background Study, SIL International, SIL Electronic Survey Report 2011-028, March 2011.

Onghokham, 2008. Anti Cina, Kapitalisme Cina dan Gerakan Cina, Sejarah Etnis Cina di Indonesia, Komunitas Bambu, Jakarta.

Rahoyo, Stefanus, 2010. Dilema Tionghoa Miskin, Tiara Wacana, Yogyakarta.

Reid, Anthony, 2011. Chinese on The Mining Frontier in Southeast Asia dalam Chinese Circulations, Capital, Commodities, and Networks in Southeast Asia, Editor Eric Tagliacozzo dan Wen-Chin Chang, Duke University Press, Durham dan London, pp. 21-36.

Suryadinata, Leo, 1978. The Chinese Minority in Indonesia, Seven Papers, Chopment Enterprises, Singapore. 1984. Dilema Minoritas Tionghoa, Diterjemahkan oleh Wilandari Supardan, Grafiti Press, Jakarta. ,2002. Negara dan Etnis Tionghoa, Kasus Indonesia, LP3ES, Jakarta. 
2007. Understanding

The Ethnic Chinese in Southeast Asia, Institute of Southeast Asian Studies, Pasir Panjang-Singapore.

2010. Etnis Tionghoa

dan Nasionalisme Indonesia, Sebuah Bunga Rampai 1965-2008, Kompas Media Nusantara, Jakarta.

Tan, Mely G., 1991. The Social and Cultural Dimension of The Role of Ethnic Chinese in Indonesian Society dalam Indonesia, Vol. 51, The Role of Indonesian Chinese in Shaping Modern Indonesian Life (1991), pp. 113-125, Dipublikasikan oleh Southeast Asian Program Publications at Cornell University, akses 14/11/2011 23:45

1997. The Ethnic Chinese in Indonesia: Issues of Identity dalam Ethnic Chinese as Southeast Asians, Editor Leo Suryadinata, Institute of Southeast Asian Studies dan Allen \& Unwin, Pasir Panjang dan New South Wales.

2008. Etnis Tionghoa di Indonesia, Yayasan Obor Indonesia, Jakarta.

Tjhin, Christine Susanna, 2007. The Chinese Indonesians' Role in Substantiating Sino-Indonesia Strategic Partnership dalam The Indonesian Quarterly, Jurnal CSIS Vol. 35 No. 4 Fourth Quarter 2007.

Tong, C.K., 2010. Between a Rock and a Hard Place: The Chinese in
Indonesia dalam Identity and Ethnic Relations in Southeast Asia, Springer Sceince+Business Media B.V. 2010, pp. 111-145.

Usman, A. Rani, 2009. Etnis Cina Perantauan di Aceh, Yayasan Obor Indonesia, Jakarta.

Vasanty, Puspa, 1999. Kebudayaan Orang Tionghoa di Indonesia dalam Manusia dan Kebudayaan di Indonesia, Diredaksi oleh Koentjaraningrat, Cetakan ke-18, Djambatan, Jakarta.

Williams, Lea E., 1960. Overseas Chinese Nationalism, The Genesis of The PanChinese Movement in Indonesia 1900-1916, The Massachusetts Institute of Technology, Massachusetts.

Willmott, Donald Earl, 1960. The Chinese of Semarang: A Changing Minority in Indonesia, Cornell University Press, Itacha dan London.

Yamamoto, Nobuto, 2011. The Chinese Connection: Rewriting Journalism and Social Categories in Indonesian History dalam Chinese Indonesians and Regime Change, Editor Marleen Dieleman, Juliette Koning, Peter Post, Brill, Leiden dan Boston, pp. 93-116. 